\title{
Case of alemtuzumab-related alopecia areata management in MS
}

Jillian K. Chan, MD, Anthony L. Traboulsee, MD, and Ana-Luiza Sayao, MD

Neurol Neuroimmunol Neuroinflamm 2019;6:e516. doi:10.1212/NXI.0000000000000516
Correspondence

Dr. Chan

jillian.chan@ubc.ca

We report a case of alopecia associated with alemtuzumab treatment for MS, the third case described in the literature, to our knowledge. ${ }^{1,2}$ A 31-year-old woman diagnosed with relapsingremitting MS in February 2015 presented with demyelinating lesions in the medulla, cerebellar peduncle, cerebellar hemisphere in addition to $>9 \mathrm{~T} 2$ supratentorial lesions on brain MRI. She was treated with an MS disease-modifying therapy (dimethyl fumarate $240 \mathrm{mg}$ twice a day) for 8 months and experienced 2 clinical relapses during this time, prompting escalation to treatment with alemtuzumab $(60 \mathrm{mg})$ in June 2016 . Her second course of treatment with alemtuzumab (36 mg) occurred in June 2017, with lymphocyte count reaching $0.5 \times 10^{9} / \mathrm{L} 30$ days posttreatment. Following alemtuzumab treatment, the patient was healthy without clinical or radiologic MS disease activity and had no other medical concerns. Two months after second course of treatment with alemtuzumab, the patient had a lymphocyte count of $0.7 \times 10^{9} / \mathrm{L}$ and experienced significant patchy hair loss, and a dermatologist confirmed the diagnosis of alopecia areata (AA). Hair loss continued over a period of 5 months, during which her lymphocyte count ranged from 0.7 to $0.8 \times 10^{9} / \mathrm{L}$. She had a positive hair pull test, indicating further hair loss, despite treatment with intralesional scalp injections of triamcinolone acetonide $(5 \mathrm{mg} / \mathrm{cc}, 3 \mathrm{cc}$ total) in most of the affected areas both on AA diagnosis and 1 month later. Six months after the second course of alemtuzumab, the patient experienced a sensory partial transverse myelitis relapse, which was acutely managed with intravenous methylprednisolone 1,000 $\mathrm{mg}$ for 5 days. Within 4 weeks after her systemic steroid treatment, hair regrowth including regions of depigmentation was noted. The patient's lymphocyte count during this time was $0.9 \times 10^{9} / \mathrm{L}$. Within 4 months of steroid treatment, hair regrowth was present over the entire scalp (figure).

\section{Discussion}

Alemtuzumab is a monoclonal antibody that targets CD52 causing T- and B-lymphocyte depletion. It is known to cause secondary autoimmunity, including thyroid disease, immune thrombocytopenic purpura, and anti-glomerular basement membrane disease. Proposed mechanisms of secondary autoimmunity with alemtuzumab include the initial induction of lymphopenia and (1) the subsequent propagation of self-antigen responsive $\mathrm{T}$ cells that escaped depletion in conjunction with an increased probability of $\mathrm{T}$ cells encountering selfantigen and/or (2) the subsequent hyperrepopulation of B cells causing secondary B-cell autoimmunity. ${ }^{3}$ Although secondary autoimmune diseases have previously been reported with various rates of occurrence, AA has been rare and only briefly described. ${ }^{4}$ One report of untreated alopecia universalis following alemtuzumab treatment in an MS patient demonstrated no improvement after a 6-months follow-up period to which the patient declined further treatments for alopecia. ${ }^{2}$ A second report of alopecia universalis associated with alemtuzumab in MS documented complete hair regrowth 2 years after the last alemtuzumab infusion despite no treatment for alopecia. ${ }^{1}$ 
Figure Alopecia areata hair regrowth after systemic corticosteroid treatment

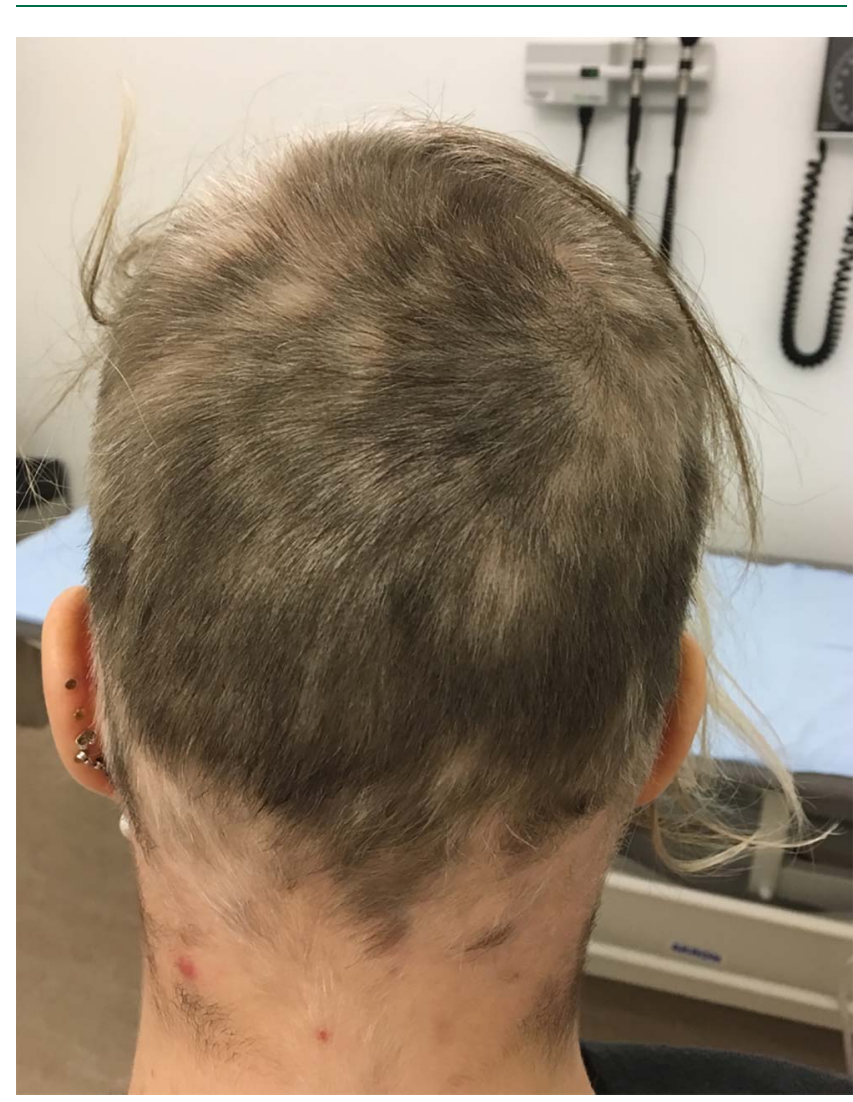

$\mathrm{AA}$ is an autoimmune disease that can involve focal or multifocal patches of nonscarring hair loss and is believed to be caused by $\mathrm{CD}^{+} \mathrm{T}$ lymphocytes attacking the hair follicle. ${ }^{5}$ This infiltration of lymphocytes causes the follicle keratinocytes to undergo apoptosis and stop the production of hair. ${ }^{5}$ AA can be treated with topical immunotherapy, intralesional scalp corticosteroids, or systemic corticosteroids (either oral or intravenous). Patients with shorter AA disease duration and less severe involvement respond well to systemic corticosteroids with higher remission rates using a common dose of $500 \mathrm{mg}$ methylprednisolone intravenous for 3 days with minimal side effects. ${ }^{6}$ Due to the autoimmune pathogenesis of AA, the immunosuppression and anti-inflammatory properties of corticosteroids can be effective.

This third case of alemtuzumab-associated alopecia shows a temporal connection with the development of an autoimmune disease similar to the other 2 cases noted. In contrast to those other cases, our patient experienced significant and rapid hair regrowth after IV methylprednisolone treatment for an acute MS relapse. Although spontaneous hair regrowth occurs in $30 \%-50 \%$ of patients with AA within the first year, it may be possible to expedite this process with the use of systemic methylprednisolone. ${ }^{7}$ Indeed, systemic corticosteroids have been successfully used to treat AA in patients who have not received alemtuzumab exposure. ${ }^{7}$ We show that systemic corticosteroids can also be considered as a treatment for alemtuzumab-related AA. Long-term follow-up of our patient is needed to determine the extent of hair regrowth and any risk of alopecia recurrence.

AA is a rare secondary autoimmune complication of alemtuzumab treatment for MS. As such, systemic corticosteroids may be an effective treatment to promote hair regrowth in patients experiencing this complication.

\section{Author contributions}

J.K. Chan helped manage the patient and wrote the manuscript. A.L. Traboulsee revised the manuscript and provided intellectual content. A.-L. Sayao managed the patient, revised the manuscript, and provided intellectual content.

\section{Acknowledgment}

The authors thank Krista Barclay for her help in managing the patient.

\section{Study funding}

No targeted funding reported.

\section{Disclosure}

J.K. Chan received travel funding from MS Society of Canada, consulted from Roche, received a fellowship grant from Biogen, Canadian Network of MS Clinics; A.L. Traboulsee served on the scientific advisory board for Sanofi Genzyme, MS Society of Canada, Canadian Institute for Health Research, CADTH, received travel funding and/or speaker honoraria from Sanofi Genzyme, Biogen, Teva, Novartis, Hoffman La Roche, MS Society of Canada, Consortium of MS Centers, received consulting fees from Biogen, Novartis, Hoffman La Roche, Sanofi Genzyme, Teva Innovation, Chugai, and received research support from Hoffman La Roche, Chugai, Novartis, Biogen, Sanofi Genzyme, Canadian Institute for Health Research, and Multiple Sclerosis Society of Canada; A.-L. Sayao received speaker honoraria from Merc-Serono, consulted for MerckSerono, Novartis, Biogen, Roche, and Genzyme. Full disclosure form information provided by the authors is available with the full text of this article at Neurology.org/NN.

Received June 22, 2018. Accepted in final form August 8, 2018.

\section{References}

1. Leussink VI, Reifenberger J, Hartung HP. Case of alopecia universalis associated with alemtuzumab treatment in MS. Neurol Neuroimmunol Neuroinflamm 2018;5:e454. doi: 10.1212/NXI.0000000000000454

2. Zimmermann J, Buhl T, Muller M. Alopecia universalis following alemtuzumab treatment in multiple sclerosis: a barely recognized manifestation of secondary autoimmunity-report of a case and review of the literature. Front Neurol 2017;8:569.

3. Baker D, Herrod SS, Alvarez-Gonzalez C, Giovannoni G, Schmierer K Interpreting lymphocyte reconstitution data from the pivotal phase 3 trials of alemtuzumab. JAMA Neurol 2017;74:961-969.

4. Willis MD, Harding KE, Pickersgill TP, et al. Alemtuzumab for multiple sclerosis: long term follow-up in a multi-centre cohort. Mult Scler 2016;22:1215-1223.

5. Paus R, Bertolini M. The role of hair follicle immune privilege collapse in alopecia areata: status and perspectives. J Investig Dermatol Symp Proc 2013;16:S25-S27.

6. Nakajima T, Inui S, Itami S. Pulse corticosteroid therapy for alopecia areata: study of 139 patients. Dermatology 2007;215:320-324.

7. Trueb RM, Dias MFRG. Alopecia areata: a comprehensive review of pathogenesis and management. Clin Rev Allergy Immunol 2018;54:68-87. 


\title{
Neurology \\ Neuroimmunology \& Neuroinflammation
}

\author{
Case of alemtuzumab-related alopecia areata management in MS \\ Jillian K. Chan, Anthony L. Traboulsee and Ana-Luiza Sayao \\ Neurol Neuroimmunol Neuroinflamm 2019;6; \\ DOI 10.1212/NXI.0000000000000516
}

This information is current as of October 19, 2018

\section{Updated Information \& Services}

References

Subspecialty Collections

Permissions \& Licensing

\section{Reprints}

including high resolution figures, can be found at:

http://nn.neurology.org/content/6/1/e516.full.html

This article cites 7 articles, 0 of which you can access for free at: http://nn.neurology.org/content/6/1/e516.full.html\#\#ref-list-1

This article, along with others on similar topics, appears in the following collection(s):

Autoimmune diseases

http://nn.neurology.org//cgi/collection/autoimmune_diseases

Multiple sclerosis

http://nn.neurology.org//cgi/collection/multiple_sclerosis

Information about reproducing this article in parts (figures,tables) or in its entirety can be found online at:

http://nn.neurology.org/misc/about.xhtml\#permissions

Information about ordering reprints can be found online:

http://nn.neurology.org/misc/addir.xhtml\#reprintsus

Neurol Neuroimmunol Neuroinflamm is an official journal of the American Academy of Neurology.

Published since April 2014, it is an open-access, online-only, continuous publication journal. Copyright

Copyright $\odot 2018$ The Author(s). Published by Wolters Kluwer Health, Inc. on behalf of the American

Academy of Neurology.. All rights reserved. Online ISSN: 2332-7812.

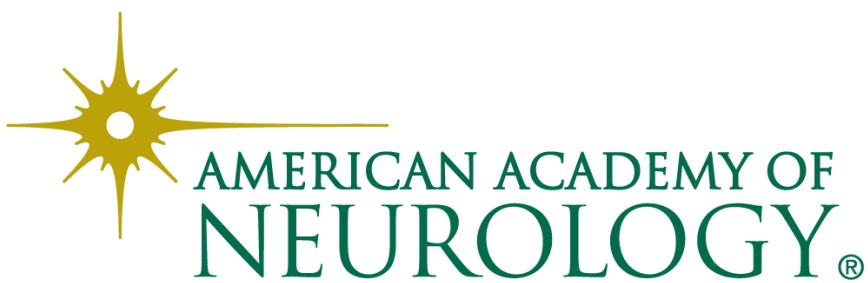

